\title{
Antioxidant and Cytotoxic Potential of Local Endemic Plant Pastinaca zozimoides Fenzl
}

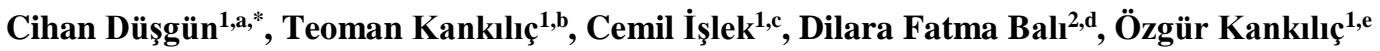 \\ ${ }^{I}$ Faculty of Science Literature, Department of Biotechnology, Niğde Ömer Halisdemir University, 51240 Niğde, Turkey \\ ${ }^{2}$ Faculty of Medicine, Medical Biology, Niğde Ömer Halisdemir University, 51240 Niğde, Turkey
}

*Corresponding author

\begin{tabular}{l|l} 
A R T I C L E I N F O & A B S T R A C T \\
\hline $\begin{array}{l}\text { Research Article } \\
\text { Received : 02/07/2020 }\end{array}$ & $\begin{array}{l}\text { P. zozimoides is local endemic in Nigde province, Turkey. There has been no previous examination } \\
\text { of the chemical composition and bioactivity of that plant extract. In this study, we studied total } \\
\text { phenolic content, antioxidant properties and cytotoxic effect of methanolic extracts of plant sample. } \\
\text { According to the Folin-Ciocalteau method, the total phenolics of the extracts were determined } \\
\text { spectrophometric. The antioxidant activity was conducted DPPH }(1,1 \text { '-diphenyl-2-picrylhydrazyl) } \\
\text { radical scavenging method and free radical reducing power assay. The cytotoxic effect was studied } \\
\text { using MTT assay cell viability on cancer cell lines as well as on Caco-2 cell lines. The total phenolic } \\
\text { content of } P \text {. zozimoides extract was found } 28.79 \pm 0.68 \mu \mathrm{g} \text { GE } / \mathrm{mg} . \text { The free radical scavenger } \\
\text { activities of the DPPH was } 31.69 \% \pm 1.61,85.15 \% \pm 0.13,86.96 \% \pm 0.085 \text { for } 1,5 \text { and } 10 \mathrm{mg} / \mathrm{mL}, \\
\text { respectively. The free radical reducing power assay was } 0.375 \pm 0.52,1.587 \pm 0.71,1.798 \pm 0.84 \text { for } 1, \\
5 \text { and } 10 \text { mg/mL compared to ascorbic acid standard. On Caco- } 2 \text { cell lines, the extract of plant } \\
\text { showed no cytotoxic potential. Because of its phenolic constituents and its antioxidant capacity it } \\
\text { can be considered a healthy nutrient. }\end{array}$ \\
$\begin{array}{l}\text { Keywords: } \\
\text { Antioxidant } \\
\text { Anticarcinogenic }\end{array}$ &
\end{tabular}

Pastinaca zozimoides

Local endemic

iD https://orcid.org/0000-0003-2796-8356 D https://orcid.org/0000-0002-6690-2846 Dittps://orcid.org/0000-0001-5565-0260

\section{Introduction}

Pastinaca is a genus that belongs to the Apiaceae family and have nine species in Turkey. Pastus means food in Latin. Parsnips are common name for the species of the genus. Since ancient times they have been used in human diet and as a traditional medicine. Five species are endemic: Pastinaca armena Fisch. \& C.A.Mey., Pastinaca gelendostensis (Y1ld. \& B. Selvi) Hand., Pastinaca trysia Stapf \& Wettst, Pastinaca yildizii Dirmenci and Pastinaca zozimoides Fenzl in Tukey,. P. zozimoides is endemic to southern parts of Turkey and distributed very small fields of Kiziltepe hill, Nigde, Turkey. It spreads in the alpine zone between $2500-3000 \mathrm{~m}$. Structure of $P$. zozimoides is biennial or perennial plant. It grows in high mountain grasses. Characteristic structure is yellow flowers and elliptical fruits. It also has intense odour.

Phytochemicals in plants that have complex biochemical, physiological and pharmacological functions have been given focus in recent years. Plants that contain bioactive phytochemicals has potential to reduce the risk of diabetes, cancer and oxidative damage (John and Shahidi, 2019). Many aromatic plants contain chemical compounds which have antioxidant properties (Gonçalves et al., 2017). These effects are due to a range of phytochemicals involving alkaloids, flavonoids, carotenoids, lignans, terpenoids, basic phenolic compound and so forth (Aarland et al., 2017). Reactive oxygen species (ROS) have been concerned with occuring degenerative disorders. Several toxic cellular processes have been associated with free radical-induced oxidative stress, including oxidative protein structure and DNA damage, lipid oxidation of cell membrane, inactivation of enzymes and carcinogenic gene anomaly (Yeldu and Ishaq, 2017). Antioxidants suppress agents by passivating free radicals, which minimize oxidative damage to biological structures. These are compounds, which increase their shelf-life when added to lipids and food-containing lipids by retarding the lipid peroxidation process. They have also been commonly used to prevent food destruction and play an significant role in 
the prevention of many diseases related aging in the way of life, being clearly tied to ROS formation and lipid peroxidation (Yeldu and Ishaq, 2017). ROS production is a natural and basic process throughout normal cell metabolism. An inequality in production of ROS and antioxidant defense systems results in oxidative stress. It has been identified as having a prominent function in the cause of many age-related and chronic disorders, cardiovascular and neurodegenerative diseases.

Taking enough antioxidants is important to prevent oxidative stress caused by radicals. Antioxidants ability of vegetables and plants has been reported to come from complete phenolics, anthocyanins and flavonoids (Earling et al., 2019; Li et al., 2017; Vicente and Boscaiu, 2018). Plants have many bioactive phytochemicals that has antioxidant, anti-inflammatory, and anticancer activities. Several reports have indicated, for example, that extracts from plants have beneficial cancer effects relative to chemotherapy or modern hormone therapies. (Eghbaliferiz and Iranshahi, 2016). Therefore, many plants were evaluated to determine for effective antioxidant and anticancer compounds, and to illustrate mechanisms for preventing apoptosis and cancer (Lopez de las Hazas et al., 2017).

$P$. zozimoides is located very small field. Very little is understood about this plant 's constituents and biological function. In this study, we aimed to determine the phenolic content of $P$. zozimoides Fenzl. It was also assesed its antioxidant and anticytotoxic activity by in vitro.

\section{Material and Method}

\section{Plant Material}

$P$. zozimoides samples were collected from plants growing spontaneously in their natural habitats. The material was authenticated by Dr. Ahmet SAVRAN (expert in botany at the department of Botanic, Nigde Ömer Halisdemir University, Department of Biology, Nigde, Turkey). Samples originating from the region of Kiziltepe hill in Nigde. It is endemic. The plants were harvested in the period between July and August 2019, corresponding to their full bloom period, and dried at room temperature $\left(20-25^{\circ} \mathrm{C}\right)$ in the research unit of the Department of Biotechnology (Nigde, Turkey). The dried plant samples were ground using a mixer into fine powder and preserved, no more than two months, in dark glass containers until their fermentation.

\section{Plant Extracts}

$P$. zozimoides leaves were shade dried and powdered. Powder sample (5g) was subjected to maceration (using magnetic stirrer) with $70 \%$ ethanol solvent for 48 hours at room temperature, allowed to undergo solution completely, and then filtered using $0.22 \mu \mathrm{m}$ Whatman filter paper. The respective filtrates were concentrated by rotary flash evaporator separately. Finally, the concentrated extracts were lyophilized and stored at $+4^{\circ} \mathrm{C}$ until use.

\section{Total Phenolic Content}

Content of phenolics was calculated using folinciocalteu reaction methods. For standard curve, various gallic acid concentrations $(10-50 \mu \mathrm{g} / \mathrm{ml})$ were prepared. 0.1 $\mathrm{ml}$ of these different gallic acid concentrations were put test tubes and added $0.5 \mathrm{ml}$ of Folin-Ciocalteu solution.
After than, 20\% anhydrous sodium carbonate solution was added to $1.5 \mathrm{ml}$, and water was used to make up to $10 \mathrm{ml}$ of volume. The absorbance was measured at $760 \mathrm{~nm}$, after 2 hour of incubation at $25^{\circ} \mathrm{C}$. $0.1 \mathrm{ml}$ extract solution (1 $\mathrm{mg} / \mathrm{ml}$ concentration) is taken and treated as previously. Absorbance of all samples was determined and equivalents of gallic acid (GAE) were calculated by the normal curve analysis. Results of absorbance were described as $\mu \mathrm{gGAE} / \mathrm{mg}$.

\section{DPPH Radical Scavenging Activity}

Scavenging activity of free radical of plant extracts was measured using the procedure described by BrandWilliams et al. (1995), with some modifications. In a tube, $150 \mu \mathrm{L}$ of $0.1 \mathrm{mM}$ DPPH (2,2-diphenyl 1-picrylhydrylase) was mixed with $100 \mu \mathrm{L}$ sample at various concentrations $(1,5,10 \mathrm{mg} / \mathrm{mL})$. After stirring for 30 minutes at room temperature in darkness, absorbances were measured against methanol at $517 \mathrm{~nm}$. The percentage of DPPH scavenging activity was calculated using following formula;

$$
\% \mathrm{DPPH}=\frac{\mathrm{AB}-\mathrm{AS}}{\mathrm{AB}} \times 100
$$

where $A_{B}$ is the absorbance of the control, and $A_{S}$ the absorbance of the sample (Brand-Williams et al., 1995).

\section{Reducing Power Activity}

The reducing power activity was determined by the procedure described by Sujatha and Sekar (2019) only minimal improvements. $0.5 \mathrm{~mL}$ of extract of sample, 0.5 $\mathrm{mL}$ of phosphate buffer $(0.2 \mathrm{M}, \mathrm{pH}: 6.6)$ and $0.5 \mathrm{~mL}$ of $1 \%$ potassium ferricyanide were added a test tube. The mixture was incubated for $20 \mathrm{~min}$ at $50^{\circ} \mathrm{C}$. In order to end the reaction, $1.5 \mathrm{~mL}$ of $10 \%$ trichloroacetic acid solution was mixed after cooling. Added $0.5 \mathrm{~mL}$ of $0.1 \%$ ferric chloride and estimated absorbance in $700 \mathrm{~nm}$. Increased absorbance of the mixture of reactions suggests increased power reduction.

\section{Cell Culture}

Caco-2 cell line (ATCC HTB-37) cells were kept at $37^{\circ} \mathrm{C}$ in an incubator at 5 percent $\mathrm{CO}_{2} / 95$ percent o 2 humidified atmosphere. Cells were developed in the updated Dulbecco Eagle medium (DMEM) containing 5 percent bovine fetal serum (FBS), $100 \mu \mathrm{g} / \mathrm{ml}$ streptomycin, 100 units/ml penicillin, and $2 \mathrm{mM}$ L-glutamine.

\section{Cell Viability}

The MTT assay, which is based on the cleavage of a tetrazolium salt by mitochondrial dehydrogenases in viable cells, measured the cell viability (Hansen et al., 1989). ATCC HTB-37 cells were seeded at 1.2 x 105 cells $/ \mathrm{ml}$ in a 96 well plate. Cells were treated with various concentrations of total extracts $(4,20$, and $100 \mu \mathrm{g} / \mathrm{ml})$ sixteen hours after plating and 1 hour later $1 \mathrm{mM}$ of $\mathrm{H} 2 \mathrm{O} 2$ was added to culture. The cells were incubated at $37^{\circ} \mathrm{C}$ for another 24 hours. The cells were incubated at $37^{\circ} \mathrm{C}$ with 20 $\mu \mathrm{l}$ of MTT stock solution $(5 \mathrm{mg} / \mathrm{ml})$ in a $200 \mu \mathrm{l}$ medium over the last 4 hours. Samples were then taken with acidic isopropanol and an ELISA reader was used to measure absorbance (Bio-Rad, USA) at $570 \mathrm{~nm}$. The relative 
viability of the cells was determined by the quantity of MTT transferred to insoluble formazan salt. The formazan's optical density formed in the control cells was taken as viability at $100 \%$. Data is average percentage of viable cells versus the controls concerned.

\section{Results and Discussion}

\section{Total Phenolic Content}

Phytochemical screening of extract shows there is presence of flavonoids, phenolics, steroids/ saponins etc. Since it was reported that the antioxidant activity of a plant extract often originates from phenolic compounds (Ghafoor et al., 2019; John and Shahidi, 2019; Lou et al., 2016). Total phenolic content in plant extract is showed in Table 1. Total phenolic content in methanolic extract of plant extract as estimated by Folin-ciocalteu Reagent method in the present study shows that plant extract show phenolic content in gallic acid equivalent (GAE). This is due to vary in nature of active ingredients in various samples. Total phenolic content was observed in $P$. zozimoides $28.79 \pm 0.68 \mu \mathrm{g}$ GAE$/ \mathrm{mg}$. Phenolic content was reported to show antioxidant activity (Aryal et al., 2019). Another study of phenolic content conducted some plant ethanolic extracts showed that phenolic content worked in this study may be good antioxidant agent (Koley et al., 2016). A study showed that Pastinaca genus shows phenolic content (Jianu et al., 2020). Therefore, $P$. zozimoides may be consumed as a natural source for antioxidant phenols and be attributed health benefits.

\section{DPPH Radical Scavenging Activity}

Free radicals are considered to be a major factor in biological destruction, and DPPH was used to determine natural antioxidant free radical-scavenging activity. DPPH, which is a radical itself with a violet color, transforms into a stable compound with a yellow color when reacting with an antioxidant and the degree of the reaction depends on the antioxidant's hydrogen donating ability. Table 2 displays the DPPH radical plant extract scavenging activity that is measured in percentage terms. $P$. zozimoides had activity against antioxidants. Less difference with plant sample was observed at lower concentration in DPPH scavenging activities. But as concentration increases the disparity in the study of scavenging events becomes more important.

\section{Measurement of Reducing Power}

The ability to reduce the oxidation potential of oxidants is determined by reducing the power method for determining antioxidant activity. The sample's reducing powers due to the capacity to donate hydrogen. Standard ascorbic acid was used in this assay. Increased reaction mixture absorbance indicates an increase in power reductions. In the present analysis for the determination of the reduction potential of different extracts as well as normal indicates, there is an increase in absorbance with respect to the change in concentration. In the present analysis for the determination of plant extract power reduction as well as normal indicates, there is an improvement in absorbance as regards concentration growth. Extract of $P$. zozimoides shows good antioxidant action (Table 3).
Table 1. Total Phenolic Content ( $\mu \mathrm{g}$ GAE /mg of extract)

\begin{tabular}{|c|c|}
\hline & P. zozimoides extract \\
\hline Total phenolic content & $28.79 \pm 0.68$ \\
\hline
\end{tabular}

Table 2. DPPH radical scavenging IC50 values (\%)

\begin{tabular}{l|c}
\hline Concentration & P. zozimoides extract \\
\hline $1 \mathrm{mg} / \mathrm{mL}$ & $31.69 \pm 1.61$ \\
$5 \mathrm{mg} / \mathrm{mL}$ & $85.15 \pm 0.13$ \\
$10 \mathrm{mg} / \mathrm{mL}$ & $86.96 \pm 0.085$ \\
\hline
\end{tabular}

Table 3. Free radical reducing power assay

\begin{tabular}{l|cc}
\hline Concentration & P. zozimoides extract & Ascorbic acid \\
\hline $1 \mathrm{mg} / \mathrm{mL}$ & $0.375 \pm 0.52$ & $0.571 \pm 0.38$ \\
$5 \mathrm{mg} / \mathrm{mL}$ & $1.587 \pm 0.71$ & $1.754 \pm 0.62$ \\
$10 \mathrm{mg} / \mathrm{mL}$ & $1.798 \pm 0.84$ & $1.984 \pm 0.75$ \\
\hline
\end{tabular}

Values expressed in mean \pm S.D. $(\mathrm{n}=3)$.

\section{Cytotoxic Activity}

$P$. zozimoides extract showed antioxidant properties. It is known that free radicals play an important role in cancer formation (Godwin et al., 2019; Pérez-Sánchez et al., 2017; Zhdanov et al., 2017). Therefore, it was thought that the plant extract would have anticancer properties. Concentrations of 1,5 and $10 \mathrm{mg} / \mathrm{mL}$ of plant samples on cell lines were studied. As a result, plant extracts did not show any cytotoxic effects at any concentration.

\section{Conclusion}

Plants are important natural sources for biological activity. In this study, the biological activity of Pastinaca zozimoides has been assessed for the first time. In this study, Pastinaca zozimoides showed antioxidant activity. Incidentally this extract also showed the high phenolic content. This plant sample has not the anticarcinogenic effect on cell lines. The findings indicate that the plant samples showed a connection between the overall phenolic content and antioxidant activity. As a result, the methanolic extracts of this plant can be used as a source of antioxidants. However, it is not suitable to be used as an anti-carcinogenic agent. It is thought that these results will be lead to the subsequent works that will be done on $P$. zozimoides.

\section{References}

Aarland RC, Bañuelos-Hernández AE, Fragoso-Serrano M, Sierra-Palacios EdC, Díaz de León-Sánchez F, Pérez-Flores LJ, Rivera-Cabrera F, Mendoza-Espinoza JA. 2017. Studies on phytochemical, antioxidant, anti-inflammatory, hypoglycaemic and antiproliferative activities of Echinacea purpurea and Echinacea angustifolia extracts. Pharmaceutical Biology, 55(1): 649-56.

Aryal S, Baniya MK, Danekhu K, Kunwar P, Gurung R, Koirala N. 2019. Total phenolic content, flavonoid content and antioxidant potential of wild vegetables from Western Nepal. Plants, 8(4): 96-108.

Brand-Williams W, Cuvelier ME, Berset C. 1995. Use of a free radical method to evaluate antioxidant activity. LWT-Food Science and Technology, 28(1): 25-30.

Earling M, Beadle T, Niemeyer ED. 2019. Açai Berry (Euterpe oleracea) dietary supplements: variations in anthocyanin and flavonoid concentrations, phenolic contents, and antioxidant properties. Plant Foods for Human Nutrition, 74(3): 421-29. 
Eghbaliferiz S, Iranshahi M. 2016. Prooxidant activity of polyphenols, flavonoids, anthocyanins and carotenoids: updated review of mechanisms and catalyzing metals. Phytotherapy Research, 30(9): 1379-91.

Ghafoor K, Ahmed IAM, Doğu S, Uslu N, Fadimu GJ, Al Juhaimi F, Babiker EE, Özcan MM. 2019. The effect of heating temperature on total phenolic content, antioxidant activity, and phenolic compounds of plum and mahaleb fruits. International Journal of Food Engineering, 15: 11-12.

Godwin MA, Mahithashri K, Shiney OJ, Bhagat M, Praseetha PK. 2019. Metal Incorporated g-C3N4 Nanosheets as Potential Cytotoxic Agents for Promoting Free Radical Scavenging in Cancer Cell Lines. Journal of Nanoscience and Nanotechnology, 19(9): 5448-55.

Gonçalves S, Moreira E, Grosso C, Andrade PB, Valentão P, Romano A. 2017. Phenolic profile, antioxidant activity and enzyme inhibitory activities of extracts from aromatic plants used in Mediterranean diet. Journal of Food Science and Technology, 54(1): 219-27.

Hansen MB, Nielsen SE, Berg K. 1989. Re-examination and further development of a precise and rapid dye method for measuring cell growth/cell kill. Journal of Immunological Methods, 119(2): 203-10.

Jianu C, Goleț I, Stoin D, Cocan I, Lukinich-Gruia AT. 2020. Antioxidant activity of Pastinaca sativa L. ssp. sylvestris [Mill.] Rouy and Camus Essential Oil. Molecules, 25(4): 869-80.

John JA, Shahidi F. 2019. Phenolic content, antioxidant and antiinflammatory activities of seeds and leaves of date palm (Phoenix dactylifera L.). Journal of Food Bioactives, 5: 120-30.

Koley TK, Kaur C, Nagal S, Walia S, Jaggi S. 2016. Antioxidant activity and phenolic content in genotypes of Indian jujube (Zizyphus mauritiana Lamk.). Arabian Journal of Chemistry, 9: 1044-52.
Li D, Li B, Ma Y, Sun X, Lin Y, Meng X. 2017. Polyphenols, anthocyanins, and flavonoids contents and the antioxidant capacity of various cultivars of highbush and half-high blueberries. Journal of Food Composition and Analysis, 62: 84-93.

Lopez de las Hazas M-C, Mosele JI, Macià A, Ludwig IA, Motilva M-J. 2017. Exploring the colonic metabolism of grape and strawberry anthocyanins and their in vitro apoptotic effects in HT-29 colon cancer cells. Journal of Agricultural and Food Chemistry, 65(31): 6477-87.

Lou S-N, Lai Y-C, Hsu Y-S, Ho C-T. 2016. Phenolic content, antioxidant activity and effective compounds of kumquat extracted by different solvents. Food Chemistry, 197: 1-6.

Pérez-Sánchez A, Sánchez-Marzo N, Herranz-López M, Barrajón-Catalán E, Micol V. 2017. Rosemary (Rosmarinus officinalis L) extract increases ROS and modulates Nrf2 pathway in human colon cancer cell lines. Free Radical Biology and Medicine, 108: 79.

Sujatha S, Sekar T. 2019. Free-radical scavenging activity leaf extract of Lisea laevigata gamble. International Journal of Pharmacy and Pharmaceutical Sciences, 11: 96-103.

Vicente O, Boscaiu M. 2018. Flavonoids: Antioxidant compounds for plant defence and for a healthy human diet. Notulae Botanicae Horti Agrobotanici Cluj-Napoca, 46(1): 14-21.

Yeldu MH, Ishaq S. 2017. Changes in lipid peroxidation, free radical scavengers and tumour necrosis factor-alpha in serum of wistar rats with induced thyroid dysfunction. Annual Research \& Review in Biology: 1-14.

Zhdanov AV, Andreev DE, Baranov PV, Papkovsky DB. 2017. Free radical production and detoxification in complex IV deficient cancer cells. Free Radical Biology and Medicine, 108: 104. 